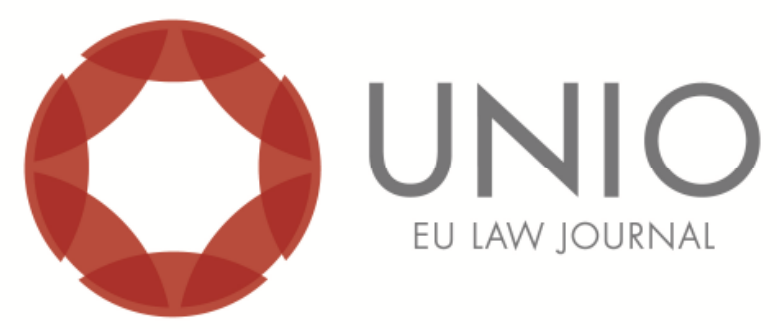

\title{
Contributions from Neuroscience and Biology to the Philosophy of Law
}

\author{
Hugo de Brito Machado Segundo*
}

\begin{abstract}
This article discusses the possibility of dealing, from a scientific point of view, with ethical standards from which one can critically evaluate positive law. For a long time it was considered that such standards would be subjective, emotional, and that they would vary according to time and place. That is why it was considered impossible, especially from a positivist point of view, to examine them using a scientific approach, due to a lack of the necessary objectivity. The findings of contemporary biology and neuroscience, however, may cast new light on this debate. Although they would not resolve the debate, these findings significantly challenge the idea that moral sentiments cannot be able to be scientifically studied.
\end{abstract}

KEYWORDS: moral philosophy - neuroscience - evolutionary biology - natural law.

\footnotetext{
* Professor of Tax Procedural Law and Legal Epistemology at Federal University of Ceará, Brazil.
} 


\section{Introduction}

For a long time the traditional opinion was that scientific knowledge could only explain objective realities. This idea may still explain the common sense understanding and the collective imaginary's perceptions of the scientist's stereotype. Even without further discussing this view of science, what matters is that it has influenced legal academia with the claim that "natural law" should not be considered as a serious research field. Indeed, "natural law" supposedly has several attributes which make it incompatible with typical "scientific" analysis, such as: subjectivity, an emotional nature, no possibility of empirical demonstration etc. Ethical, moral and natural law are perhaps the subject matter of a philosophical approach, but should never be considered in a scientific Theory of Law. The word "perhaps" has been used in the previous sentence because we know that even philosophy has been threatened by positivism. The latter intended to replace the Philosophy of Law with a General Theory of Law, which equally has universal aspirations but does not study metaphysical issues ${ }^{1}$.

This paper aims to readdress that old problem. The aim is not so much to question the view of scientific knowledge mentioned in the last paragraph, which will be briefly discussed, but rather, the aim is to examine the manner in which the current state of the art of neuroscience and evolutionary biology calls into question the idea that "natural law" cannot be scientifically studied, while still maintaining the positivist epistemological paradigm. In addition to reporting how a few findings in those areas provide a scientific account of moral sentiments and their reflections in the context of human societies, we intend to critically examine how those findings can contribute to a proper understanding of the law. In the last part of the article, we will approach possible contributions of neuroscience and biology to the Philosophy of Law by joining, albeit briefly, the debate about how science has allegedly become superior to philosophy, in order to find out if the distance between the two disciplines becomes even greater, when consideration is given to the advances in science, revealing the secrets of the human brain.

\section{Natural law's lack of scientificity under the positivist paradigm}

This article does not aim to examine the history of positivism and its branches or divisions within Legal Theory ${ }^{2}$. Perhaps it should suffice to know that, from a positivist perspective of science, which claims that scientific knowledge is descriptive and objective, science can only examine issues which can be logically or empirically verifiable. Everything that does not fit that description would be considered metaphysical, emotional and subjective. As we know, this is the main reason why the positivist approach of Law refuses to examine issues related to natural justice or the so-called "natural law". Modern scientists must accept "reality as it is, trying to understand it based on a purely experimental conception"3, which

\footnotetext{
${ }^{1}$ RADBRUCH, Gustav. Filosofia do Direito. Tradução de Cabral de Moncada. (Coimbra: Armenio Amado, 1997) 73.

${ }^{2}$ For more on this topic, see v.g., BOBBIO, Norberto. O positivismo jurídico. Tradução e notas de Marcio Pugliesi, Edison Bini e Carlos E. Rodrigues. (São Paulo: Icone, 1995).

3 BOBBIO, Norberto. O positivismo jurídico. tradução e notas de Marcio Pugliesi, Edison Bini e Carlos E. Rodrigues. (São Paulo: Icone, 1995), 135-136.
} 
is why one may review norms, regulations, judicial decisions, behaviors, social facts but never values based on which such realities could be judged.

An important pillar of this world view lies in the distinction between fact-based judgments and value judgments as well as the logical impossibility of extracting the latter from the former, based on David Hume's classical allusion to the "naturalistic fallacy", also known as the is-ought problem". Through fact-based judgments, which are "objective", one can describe reality as it is. Through value judgments one may decide whether reality is good or bad based on the ideal notion of how reality should be. Scientific knowledge would consist of the first type of judgment, avoiding the latter at all costs. After all, science is based on experience, on empirical observation, and "experience teaches us that a thing is so and so, but not that it cannot be otherwise" . This is why legal positivism proposes that legal scientists should only describe the law as it is, paying no regard to how it should or could be. While there are, of course, disagreements about what should be considered as such, whether it should be legislative acts or norms, standards, practices of judges, or the response of society to these standards. Nevertheless, all these different views converge on one point: all those possible objects are "objective"; they can be submitted to "objective" analysis. Scientists are interested in the validity rather than the value of a legal order.

I should clarify, however, that this article is not defending that view of natural law or natural law theories. Neither is it defending such a view of Science. We know there are authors who defend contemporary forms of natural law which do not fit the aforementioned stereotype. Dworkin ${ }^{6}$ and John Finnis ${ }^{7}$ are examples of thinkers who hold this view. In fact, the aim of this discussion is to revisit the view of natural law built by its main positivist detractors, despite the fact that it may suffer the so-called "Straw Man fallacy", according to which one builds a caricatured version of the idea under objection, in order to make it easier to criticize it. The purpose of this analysis is to show that even this caricatured "Natural Law" deserves to be revisited or reanalyzed due to a number of discoveries in biology and neuroscience.

\section{Possible objections to this paradigm}

The view of legal science discussed above raises a number of criticisms and objections. First, even someone who accepts that idea of science can question its sufficiency and support the need to complement its approach with other methods of inquiry, such as Philosophy for instance. The deepest objection, however, may be one that affects the very epistemological assumptions of the positivism paradigm.

Indeed, as a matter of fact, scientific knowledge is not only made by disinterested observations, and the scientist is not someone who merely describes an objective reality. The scientific process is value-oriented from the very moment when the object to be studied is chosen and identified. Otherwise, one would be able to find scholars dedicating their time to counting the exact number of grains

\footnotetext{
${ }^{4}$ HUME, David. Tratado da natureza bumana. 2.ed. Tradução de Déborah Danowski. (São Paulo: Unesp, 2000), Book 3, Part 1, Section 1, \27, p. 509.

5 KANT, Immanuel. Critique of pure reason. Translated by Paul Guyer and Allen W. Wood. (Cambridge: Cambridge University Press, 1998), 137.

${ }^{6}$ DWORKIN, Ronald. 'Natural law' revisited. University of Florida law review, (Florida, v. XXXIV, n.2, p. 165-188, winter of 1982).

7 FINNIS, John. Lei natural e direitos naturais. Tradução de Leila Mendes. (Rio Grande do Sul: Unisinos, 2007).
} 
of sand on a certain beach, or counting the number of bathroom tiles in the University where they teach. This would be as common as seeing researchers trying to find ways to stop the growth of malignant tumor, for example, or trying to understand the causes of urban violence or poverty.

In fact, knowledge develops from identifying problems and testing possible solutions to those problems. This occurs even in the most primitive life forms. Interactions with the environment are inherent to any system, and there is no interaction without information. In other words, in order to be understood as such and to interact with its immediate environment, a system requires information about itself, its environment and how to react to it. For example, living things need to know the temperature of the surrounding environment and how appropriate or inappropriate it is in order to escape from the extreme heat that could damage their molecular structure and therefore their livelihood. Consequently, the first problem that gives rise to knowledge is survival. To solve this problem, natural selection finds a wide range of solutions in a trial and error process.

Evidently, the word "knowledge" can be used in a broader sense, as in the previous paragraph, to refer to situations in which there is not necessarily any awareness or conscientiousness. In this sense, bacteria "know" how to get food, digest it, generate energy, reproduce etc. even though, as single-cell organisms, they obviously lack consciousness. However, even without consciousness there is information, some of it already stored inside living beings and some of it obtained from their interactions with the environment. That information and the way it is handled are stored in the genetic code of each living being ${ }^{8}$, where knowledge about an organism's formation and operation has been recorded for over millions of generations. Living beings favored with the best information have increased their chances of survival and reproduction. Over millions of years, a substantial amount of data (how to make, maintain and regenerate cells, tissues, organs, systems, etc.) is therefore selected, refined and stored in the DNA of every living being.

In contrast, one could argue that this is not the kind of knowledge that people talk about when dealing with Science. This objection, however, is unfounded since human knowledge does not develop so differently. In fact, knowledge can be understood more narrowly as a relationship established between a subject who knows and an object that is known and under which the subject builds an image of that object; but knowledge can also be understood as the unfinished product of this relationship. In any case, one cannot deny that it unfolds in similar terms to those observed in the process of the natural selection, of which it is ultimately a product of?.

Indeed, the human brain has an understanding of the world around it, built on information that is collected by imperfect senses - imperfect, or just good enough to allow survival ${ }^{10}$. This information is interpreted based on prior-knowledge that come from past experiences of the same individual or its ancestors ${ }^{11}$. The brain's understanding of the reality around it is imperfect and, as such, temporary, subject

\footnotetext{
${ }_{8}$ AFTALIÓN, Enrique R.; VILANOVA, José; RAFFO, Julio. Introducción al derecho. (Buenos Aires: Abeledo-Perrot, 2004), 41-47.

${ }_{9}^{9}$ RIDLEY, Matt. The rational optimist: how prosperity evolves. (New York: Harper Collins, 2010), 5.

${ }^{10}$ NICOLELIS, Miguel. Muito além do nosso eu. (São Paulo: Companhia das Letras, 2011), 452.

11 POPPER, Karl. O mito do contexto: em defesa da ciência e da racionalidade. Tradução de Paula Taipas. (Lisboa: Edições 70, 2009), 108; NOZICK, Robert. Invariances. The structure of the objective world. (Cambridge: Harvard University Press, 2001), 108; GAZZANIGA, Michael S. Who's in charge? Free will and the Science of the brain. (New York: Harper Collins, 2011), 51.
} 
to a constant process of confirmation or correction. Human beings are aware that eventually their senses can be deceiving about their immediate physical reality, but those same senses are the only possible access to that reality. Therefore, they must submit the impressions obtained from their senses to constant examination ${ }^{12}$. Thus, neuroscience has somehow confirmed claims made long before by hermeneutics theorists such as Husserl and Gadamer, for example.

With the emergence of the so called mirror neurons throughout the evolutionary process, neurons that allow an individual to put himself or herself in someone else's shoes, seeing that other people are like him or her and wondering, within this context, what he or she might be feeling, ideas such as empathy, moral feelings and language have also emerged, and those ideas are essential to human knowledge $^{13}$. Naturally, a more complex neurological system also evolved together with mirror neurons ${ }^{14}$, so we cannot say that mirror neurons alone are responsible to all human superior capabilities ${ }^{15}$. Anyway, with language and the capability to create institutional realities, individuals were able to apply the same logic of natural selection to ideas. Instead of disappearing, living beings who have recorded an inadequate way to solve a problem in their DNA could observe - or hear, or read another being that had found a more appropriate way to solve the same problem and learn how to do the same. This is the reason why I said before that human knowledge is a direct product of natural selection, somehow reflecting it.

In one way or another, this shows that problems are identified first and solutions proposed afterwards, modeled on the individual's preconceptions of those problems and possible ways of resolving them. Such preconceptions can result from past experiences of their ancestors and become reflected in DNA, thus forming instincts that give individuals a prior record of how to react in such situations ${ }^{16}$. Nonetheless, they can also result from past experiences of the same individual, which are kept in his memory. In any case, whether arising from instincts, from past experiences of the same individual or from observation of third-party experiences, those proposals are tested and the best options are selected. There is no definitive solution; it is always possible to come up with a different, more appropriate or efficient one.

This, as we know, is the basis of Karl Popper's epistemology of fallibilism ${ }^{17}$. It is also how the process of natural selection unfolds and how human cognition occurs in general. There is no reason to understand that scientific knowledge is processed in a radically different way. Despite its being more concerned with systematicity, it is nonetheless a species of the genus buman cognition.

On the other hand, we know that the reality is more complex than our human capacity to understand it. Therefore, the brain simplifies it by eliminating or

\footnotetext{
12 RESCHER, Nicholas. Epistemology - An Introduction to the Theory of Knowledge. (Albany: State University of New York Press, 2003), 83.

13 RAMACHANDRAN, V. S., The tell-tale brain: a neuroscientist's quest for what makes us buman. (New York: WW. Norton \& Co. 2011), 117.

${ }^{14}$ LIEBERMAN, Matthew D. Social. Why our brains are wired to connect. (Oxford University Press, ibooks, 2013).

${ }^{15}$ Especially because, it is important to remember, mirror neurons were initially found in macaques, not in humans, so they cannot be the unique explanation for all human capabilities. Cf. HICKOK, Gregory. The mith of mirror neurons. The real neuroscience of communication and cognition. (New York: W. W. Norton \& Company, 2014).

${ }^{16}$ GAZZANIGA, Michael S. Who's in charge? Free will and the Science of the brain. (New York: Harper Collins, 2011), 51.

${ }_{17}$ POPPER, Karl. A vida é aprendizagem - Epistemologia evolutiva e sociedade aberta. Tradução de Paula Taipas. (São Paulo: Edições 70, 2001), 17.
} 
disregarding some of its parts which are considered irrelevant for the main purpose of understanding. Consequently, someone wishing "only to describe" a portion of reality should, based on the reasons for that "mere description", chooses which aspects will be highlighted and which are going to be ignored. And there is more: they must establish the boundaries between the object being described and the remaining parts of reality, once again taking into account the main purpose of the description. For instance, if someone wants to "describe" the distance between Fortaleza and Recife (two cities in Northeastern Brazil), a few meters or even kilometers will certainly be disregarded if the purpose of the description is to calculate the time it takes to fly from one city to the other. However, if description pertains to an individual's height so that he or she can buy clothes, this requires greater accuracy, although centimeters or even millimeters can be disregarded ${ }^{18}$. Those millimeters are going to be essential, however, if the description is made by a student who wishes to borrow some graphite leads for his or her mechanical pencil, they need to be clear about whether they need a 0.5 or 0.7 lead.

Thus, even if one understands the process of scientific inquiry as being "merely descriptive" of reality "as it is", one would have to admit that values guide the choice of what will be described and the determination of aspects to be taken into account in this activity. That description consists of having reality "reconstructed" by whoever is studying it. The purpose is to confirm or rectify a previous construction about that very same notoriously imperfect reality. Therefore, one cannot categorically refrain from considering values, even when referring to "descriptive" science, because the very notion that values must be removed from a scientist's work is itself markedly guided by values and is, as such, contradictory.

In light of the above, we can make the following conclusions, which defeat the epistemological foundations of a positivist view of science: (i) reality is not "merely described" by the one studying it; it is in fact rebuilt by him or her through imperfect senses, which provide information to the brain that is to be interpreted based on existing preconceptions ; (ii) when describing reality, researchers choose which parts of it are going to be considered and which are going to be disregarded; (iii) precisely because knowledge is made from imperfect reconstructions of reality, it is essentially temporary and rectifiable.

Most notably, however, even for those who insist on holding on to the positivist epistemological paradigm, eventually finding solid reasons to overcome each of those objections ${ }^{19}$, it is difficult to support the thesis proposing that factbased judgments and value judgments (is and ought distinction) are subject to detached separation, and that moral sentiments are entirely emotional and subjective and, as such, are incompatible with purely descriptive scientific analysis. The problem in this case arises from the latest discoveries in Biology and Neuroscience, an issue we will examine in the next section of this paper.

\section{Biology, neuroscience and moral sentiments}

Contemporary biology has conclusively revealed that natural selection is not necessarily related to selfish behavior. Darwin had already made that statement;

\footnotetext{
${ }^{18}$ DEEMTER, Kees Van. Not exactly: In praise of vagueness. (Oxford: Oxford University Press, 2010), 81.

19 see MACHADO SEGUNDO, Hugo de Brito. Epistemologia falibilista e Teoria do Direito. Revista do Instituto do Direito Brasileiro da Universidade de Lisboa - RIDB Ano 3 (2014), n. ${ }^{\circ}$ 1, p. 197-260, available online in http://www.idb-fdul.com/uploaded/files/2014 0100197 00260.pdf.
} 
however in the late $20^{\text {th }}$ century, studies about primates empirically verified basic elements of political institutions and moral sentiments, especially in higher mammals ${ }^{20}$. When Richard Dawkins, for instance, metaphorically alludes to a "selfish gene" 21 , he discusses the actions of something that is a component of the DNA inside living cells, something that cannot, for obvious reasons, have motivations - whether selfish or not - for its "actions". Nevertheless, such actions may allow the selection of individuals equipped with neural systems that allow the emergence of genuinely selfless actions and behaviors ${ }^{22}$.

As a matter of fact, relationships among living beings in the struggle for survival involve what in game theory is known as the "non-zero sum game". "Zero sum" games are those in which a participant scores points and the other loses the same amount, so that the sum of the overall scores is always zero. On the other hand, games known as "non-zero sum" involve the possibility of one of the participants earning points without implying prejudice, disadvantage or harm to others. This is the case of survival, because one living being's survival, nourishment or reproduction does not require all other living organisms to fail in those same tasks. Hence the emergence of cooperation, which is natural in "non-zero sum" games ${ }^{23}$.

While cooperative behaviors favor the survival of a group of individuals who adopt them, such behaviors are naturally selected even among organisms that have no consciousness, such as insects or bacteria ${ }^{24}$. Nonetheless, it is precisely because those cooperative behaviors enable the survival of groups of individuals who adopt them that they lead to the natural selection of neurological and sensory systems that, among other functions, are able to enhance that cooperation, making it more efficient and complex. That is the basis, for instance, of animal protection instincts toward their offspring, which lead to the preservation of individuals with similar genetic codes. It is also the basis for the very emergence of an even more complex neurological system in higher mammals such as chimpanzees, bonobos, dolphins and wolves, which are capable of providing moral sentiments that enable community living ${ }^{25}$.

It seems clear, indeed, that living in a community is less difficult than living in isolation, and the convenience of living in groups will be more favorable as cooperation between members of that group grows. Moreover, one individual from "outside" the group can join it to destroy its members, or even one of the previous members can stop cooperating with others (free rider). For this reason, mechanisms that allow for the recognition of individuals who cooperate or do not cooperate have been naturally selected. The same mechanism enables individuals to remember previous interactions and the behavior that other members of the group adopted then. Remembering and recognizing is not enough, though, because in large groups a single individual can interact once with another individual who does not cooperate and that he will never meet again. As a solution

20 WAAL, Frans de. Good Natured: The Origins of Right and Wrong in Humans and Other Animals. (Cambridge: Harvard University Press, 1996), 2013

${ }^{21}$ DAWKINS, Richard. The selfish gene. 2.ed. (New York: Oxford University Press, 1989).

22 WAAL, Frans de. Good Natured: The Origins of Right and Wrong in Humans and Other Animals. (Cambridge: Harvard University Press, 1996), 117.

23 AXELROD, Robert. A evolução da cooperação. Tradução de Jusella Santos. (São Paulo: Leopardo, 2010).

${ }^{24}$ AXELROD, Robert. A evolução da cooperação. Tradução de Jusella Santos. (São Paulo: Leopardo, 2010), 19; GREENE, 2013, p. 57-58

25 WAAL, Frans de. Good Natured: The Origins of Right and Wrong in Humans and Other Animals. (Cambridge: Harvard University Press, 1996), 88. 
to this problem, individuals have moral sentiments in order to approve or disapprove the conduct of others, no matter if they have interacted before or just witnessed (or heard about) a previous interaction with somebody else. Because of this, reputation and trust emerge as very important values in the community ${ }^{26}$.

Just as a nutritious food brings pleasure, and spoiled or poisoned food can cause sickness or disgust due to the natural selection process, behaviors that positively enable a group's cohesion and harmony produce pleasurable sensations in individuals who witness or adopt them, leading such behavior to be appreciated and encouraged. And actions that lead to the opposite result, that is, to disharmony and tension in the group, produce negative feelings that lead others to inhibit or censor those actions. This is the reason for stating that moral feelings originate in natural selection, a subject in which we have relative agreement among biologists today ${ }^{27}$.

Franz de $\mathrm{Waal}^{28}$, by the way, says that, reading books like $A$ Theory of Justice ${ }^{29}$,an influential book by the contemporary philosopher John Rawls, I cannot escape the feeling that rather than describing human innovation, it elaborates on ancient themes, many of which are recognizable in our nearest relatives. Of course, everything is more explicit in human society because of our ability to formulate rules of conduct, discuss them among ourselves, and write about them in exquisite detail. Still, it is safe to assume that the actions of our ancestors were guided by gratitude, obligation, retribution, and indignation long before they developed enough language capacity for moral discourse.

According to those ideas, authors such as Joshua Greene ${ }^{30}$ use those biological concepts as a foundation for revisiting known moral issues such as those related to the trolley problem, the well-known experiment used by moral philosophy scholars $^{31}$. The trolley problem can be described succinctly as follows: a runaway trolley runs along rail tracks. There are five workers on the rail tracks right ahead. The trolley can be diverted to a different track, where only one worker is stood . Would it be morally right to turn the trolley to the alternative track and kill one person in order to save five? A positive response in this case is quite often: yes, it would be correct to change the course of the trolley to save five people, even if it causes one death. A few changes in the experiment can make things more difficult and slightly different. In one of such instances, is a scenario in which; instead of an alternative track, there is a very fat man on a bridge above the rails, and the question is whether it is fair to push this man onto the rails so he can hit the trolley and stop it, saving the five people at the end of the track. This time, however, most people do not approve of pushing and killing the fat man, even if it leads to

26 PINKER, Steven. Como a mente funciona. Tradução de Laura Teixeira Motta. (São Paulo: Companhia das Letras, 1998); AXELROD, Robert. A evolução da cooperação. Tradução de Jusella Santos. (São Paulo: Leopardo, 2010), 14; WAAL, Frans de. Good Natured: The Origins of Right and Wrong in Humans and Other Animals. (Cambridge: Harvard University Press, 1996), 113; GREENE, Joshua. Moral Tribes. (New York: Penguin, 2013), 112.

27 RUSE, Michael. Evolutionary ethics: a phoenix arisen. (Zygon, v. 21, n. 1, 1986), 95-112; HAUSER, Marc. Moral minds. (New York: Harper Collins, 2006); WAAL, Frans de. The bonobo and the atheist. (New York: W. W. Norton \& co., 2013); DAWKINS, Richard. The selfish gene. 2.ed. (New York: Oxford University Press, 1989); DAWKINS, Richard. The god delusion. (London: Bantam Press, 2006).

28 WAAL, Frans de. Good Natured: The Origins of Right and Wrong in Humans and Other Animals. (Cambridge: Harvard University Press, 1996), 161.

${ }^{29}$ RAWLS, John. A theory of justice. (Oxford: Oxford University Press, 1980).

${ }^{30}$ GREENE, Joshua. Moral Tribes. (New York: Penguin, 2013).

31 eg, SANDEL, Michael J. Justice - what's the right thing to do. (New York: Farrar, Straus and Giroux, 2009). 
saving five people at the at the expense of a single life, just as in the first form of the experiment.

There is extensive literature concerning philosophical discussions around this issue, investigating the distinctions between the two situations and their reflections on the study of utilitarian theories, as Kantian and many others. Dawkins ${ }^{32}$ and Hauser $^{33}$, for example, see the disgust in pushing the fat guy, even to save five lives, as a reflection of the Kantian categorical imperative, because the problem is using the man as a thing or as a mere means to an end, equating it to a stone. In the situation where the trolley is shifted to an alternative track, the guy who dies at the end of the alternate route is not used as a means to an end, and his death is just an unwanted negative side effect. Incidentally, if the worker was not at the end of the rail, the detour could be done in just the same way, saving the very same five workers.

Joshua Greene $e^{34}$, however, uses the notions of biology that we already mentioned, combined with discoveries from neuroscience and brain imaging which assess in real time the brain function of people undergoing the above trolley problem experiment. He then tries to answer those questions in a less speculative and more empirically-grounded fashion, investigating why in some cases an action that leads to the death of one person to save five lives seems correct while it seems wrong in other cases, even though people often cannot give good reasons to support their choice. People feel, firstly, that an action is right or wrong and then try to find or create reasons to justify their choice. Greene does not believe that the explanation is simply the innate character of something such as Kant's categorical imperative, and so he proceeds to making some changes to the experiment. Let us suppose that the alternative track where the worker stands alone is not a "dead end", but in fact it takes the trolley back to the main track where there are the five workers who must be saved. In this case, the absence of that lone worker would make the diversion ineffective: the trolley will return to the main track and kill all five workers. So, with this change in the thought experiment, the lone worker in the alternative track is like an obstacle, such as a stone or the fat man being pushed onto rails from a bridge. In fact, he will be a mere tool to prevent the trolley from returning and killing the other five. Nevertheless, even if they do not clearly know why, many people choose to change the trolley's path, or at least they think that this detour appears to be less unpleasant than pushing the fat man onto the rails, even if it aims to achieve the same purpose of killing one to save five.

For Greene, what actually occurs is that we have been biologically selected to have a certain level of repulsion for actions that have violence as an immediate end, such as pushing someone to death, but we do not have the same perception of acts in which the death of someone appears as a remote or indirect end, and not as the most immediate goal.

Within this context, we can start a rich and important discussion about conscious and unconscious forms of human reactions to moral questions, which Greene $^{35}$ studies based on the ideas of Daniel Kahneman ${ }^{36}$ regarding two forms of human behavior, which he named "automatic" and "manual". Automatic behavior is mainly intuitive and, to some extent, instinctive. It is fast and efficient at solving

\footnotetext{
32 DAWKINS, Richard. The god delusion. (London: Bantam Press, 2006), 214.

${ }^{33}$ HAUSER, Marc. Moral minds. (New York: Harper Collins, 2006).

${ }^{34}$ GREENE, Joshua. Moral Tribes. (New York: Penguin, 2013).

35 GREENE, Joshua. Moral Tribes. (New York: Penguin, 2013), 320.

${ }^{36}$ KAHNEMAN, Daniel. Thinking, fast and slow. (New York: Farrar, Straus and Giroux, 2011).
} 
problems that are similar to the ones that led to its formation. That behavior can be generated by natural selection from the unconscious behaviors of ancestors, or by unconscious memories of past experiences of the same individual. For this reason, however, the "automatic mode" is unable to deal with new and unusual situations $^{37}$. On the other hand, manual behavior, which is known as conscious or rational, is slower and it involves greater cognitive effort. Meanwhile, it is flexible and can handle new situations. A sample of those two types of action can be seen when someone is trying to learn how to drive. In the beginning, this person must pay a lot of (conscious) attention to actions such as shifting gears or pressing pedals; however, after some practice, the subject simply drives while only focusing on where he is going, without consciously thinking about which gear he has to shift to or what pedals are supposed to be pressed.

Shaped by millions of years of natural selection, in their "automatic mode" human beings have mechanisms that push them to collaborate with people that they view as being from their own group. For this reason, in the relationship between an individual and his peers and in a "Me versus us" conflict, feelings of cooperation will allow for situations where the former does not always prevail upon the latter. This is why sometimes people act in a genuine and disinterested form of altruism, or why they experience some satisfaction witnessing such actions, even when whoever benefits from them is someone to whom they are not related or from whom nothing is expected in return ${ }^{38}$. That is regarded today as the origin of moral sentiments.

The problem is that those mechanisms fail or do not work well when the "other" with whom the individual is supposed to cooperate is seen as someone from outside his or her group. This creates conflict, not between "Me vs. us" but rather between "Us x Them". In this case, such mechanisms from which moral sentiments arise do not promote the same selflessness. Instead, they generate a sense of competition and very often, rivalry and destruction. In other words, evolution has selected cooperative behaviors and feelings that favor intragroup but not intergroup relationships. This is reflected, for example, in religions that often preach altruistic behaviors in relation to one's "fellow creatures", a concept that is not generally remembered by many believers in regard to those who profess different religions.

Joshua Greene argues that in such situations it is convenient to adopt the same solution used by the brain in cases of conflict between two of its automatic mechanisms which lead to divergent results: deploying the manual mode. For example, when the name of a color is printed in a different color (e.g., the word "red" written in blue color), and someone asks us to quickly read the word, part of our automatic functioning brain compels us to pronounce the name of the color of the letters forming the word ("blue"), but in response another part indicates the meaning of those letters grouped together ("red"). When given two divergent behaviors suggested by our intuitive system, the "manual" mode takes over and consciously (with greater effort and more slowly) verifies what response is consistent with the question, choosing the answer that corresponds to the meaning of the letters and not the color in which they are printed.

Just as the "manual mode" is used when there are divergent solutions provided

\footnotetext{
37 To read more about instinct and its rigidity, see MIRANDA, Pontes de. O Problema Fundamental do Conbecimento. (Porto Alegre: O Globo, 1937), 19; GREENE, Joshua. Moral Tribes. (New York: Penguin, 2013), 341.

38 WAAL, Frans de. Good Natured: The Origins of Right and Wrong in Humans and Other Animals. (Cambridge: Harvard University Press, 1996), 144.
} 
by different sections of the same brain which are operating under the "automatic mode", a situation that Greene calls intracranial conflict of intuitive solutions, he suggests that this can also be done in the case of intercranial conflicts, i.e., conflicts between solutions presented by automatic or intuitive modes of different people ${ }^{39}$. When the "automatic mode" of the people involved in a moral issue is not able to provide convergent solutions to a moral conflict because they do not see each other as belonging to the "same group" (e.g., Brazilian x Saudi Arab culture regarding women's rights), there would be a case for activating the manual mode, and finding the most appropriate solution in a conscious and rational way.

The obvious problem that can arise in this case regards how to determine which is the "best rational solution". In other words, what could be used as metacriteria to judge various moral systems which "naturally" emerge in each society? This is, indeed, the great question for Moral Philosophy and the Theory of Human Rights today, which shows that those Biological and Neuroscience findings are far from making philosophical discussions a thing of the past ${ }^{40}$. After all, why should some of our moral sentiments, shaped by natural selection, be encouraged while others are inhibited or avoided? What criteria should be used to select one over the other?

According to Greene, the solution in this case should be one obtained through utilitarian reasoning. After all, rationally the best solution in case of a moral conflict is that which promotes the greatest happiness to the greatest number of people. In summary, for "easy" questions which do not involve moral conflicts, disagreements or disputes due to opposing arguments, we can rely on automatic modes and moral sentiments, which represent a better way in accordance with natural selection to generate cohesive and cooperative groups. However, in cases of dispute between opposing moral positions, when the people involved in the issue have radically different views on how to resolve it (resulting, in most cases, from the fact that they see others as being "different" and not from "the same group"), the manual mode should be employed and, in Greene's view, people should advocate an utilitarian answer to the problem, adopting the solution that maximizes the happiness of the greatest number of people.

\section{Consequences for the contemporary study of Law}

While conducting trans-disciplinary studies, usually under the label of "neuroscience", biologists, neurologists, psychologists and even artificial intelligence theorists have arrived at undoubtedly disturbing conclusions, which are also capable of revolutionizing the way ethical issues are studied.

Ethical issues, however, do not have to be solved exclusively by biologists or neurologists, considering neuroscience findings. As a matter of fact, an additional significant revelation of neuroscience is related to its own development: a new branch of knowledge stemmed from interaction between specialists from different fields, who started to communicate on the intersection points between their fields, allowing for progress far beyond the boundaries of their own specialties. A single person cannot engage in an in depth study of all subjects, but this is not a reason for a researcher to ignore what others are investigating, researching and discovering in other areas. Just as cognition and even artificial intelligence theorists ${ }^{41}$ can interact with neurologists, the same may be equally true for legal

\footnotetext{
${ }^{39}$ GREENE, Joshua. Moral Tribes. (New York: Penguin, 2013), 693.

40 CORTINA, Adela. Neuroética y neuropolítica. Sugerencias para la educación moral. (Madrid: Technos, 2011).

41 CHRISTIAN, Brian. O bumano mais bumano. O que a inteligência artificial nos ensina sobre a vida.
} 
scientists, legal scholars and legal philosophers.

One may indeed object to Greene's ideas and those of other biologists or neuroscientists who address those topics, as briefly summarized in the previous section, especially with respect to non-specific biological conclusions they may reach. For example, despite of Greene's fairly competent defense of utilitarian moral philosophy, his ideas can be subject to some improvement. One can also derive a few more practical and immediate conclusions for the study of Law.

Since each person's view of what constitutes happiness differs, along with the means or elements that lead to happiness; it is perhaps more appropriate to replace the maximization of happiness, proposed by Greene, with the maximization of freedoms. This is what is done by Amartya Sen, another competent critic of utilitarianism ${ }^{42}$. After all, with freedom, people can decide what happiness means and what the best way to pursue it is, achieving the utilitarian ideal in a more efficient way.

On the other hand, although neuroscience reinforces the idea about how subtle the distinction between fact-based judgments and value judgments is, or between descriptive propositions and evaluative propositions, one cannot say that it has completely lost its meaning and usefulness. So much so that Greene, in order to avoid the naturalist fallacy denounced by Hume, recognizes that in case of moral disagreements due to inadequate natural mechanisms that compel us toward intragroup cooperation but not toward intergroup cooperation, a consensual solution must be found. Due to a lack of a "given" criterion, by nature or by God, and as a result of the unsatisfactory nature of the relativistic solution - in fact, non-solution -, as for a relativist any solution would have equal value ${ }^{43}$, that problem must be solved by a solution built by consensus, based on a common ground on which all agree. That foundation, for Greene, is the idea that one should maximize people's happiness. But this does not avoid the naturalist fallacy. After all, why should we pursue or honor those moral sentiments, in particular cases, and for what reasons should we look for other solutions when they do not lead to altruism or cooperation as a result, or when there is conflict between the solutions such feelings dictate on different people? To answer this question, even if we manage to achieve "objectivity" in the study of moral issues, we will need to recognize that science is not merely descriptive, and that science should also provide solutions and improvements to the reality it describes. This requires a review of the positivist paradigm itself within Epistemology.

Incidentally, regardless of the purposefulness of using a criterion to resolve moral conflicts, another intelligent way to minimize the flaws of "automatic mode" behavior that often lead to those conflicts is adopting the idea advocated by Amartya Sen according to which, in the contemporary world, we are all part of several different groups at the same time. This should be taken into account in order to achieve a non-violent solution to moral conflicts ${ }^{44}$. While in the distant past, our ancestors lived in small nomadic groups with individuals with whom they had to cooperate to survive, and rival groups which were almost always a source of danger, and were very rarely found, in the contemporary world one's individuality is determined by many different factors, and this places such an individual in the

\footnotetext{
Traduação de Laura Teixeira Mota. (São Paulo: Companhia das Letras, 2013).

42 SEN, Amartya. Desenvolvimento como liberdade. Tradução de Laura Teixeira Motta. (São Paulo: Companhia das Letras, 2000).

${ }^{43}$ So we could choose among them using a dice, as ironically says GREENE, Joshua. Moral Tribes. (New York: Penguin, 2013), 684.

44 SEN, Amartya. Identity and violence. (New York: W.W. Norton \& Company, 2006).
} 
most diverse groups at the same time.

To use an example, let us imagine a teacher who is a Flamengo (soccer team) fan. He is an atheist, a liberal and the father of a child with visual impairment. When it comes to sports, his rival would be a Fluminense supporter. In a soccer match, at the Stadium, they would see each other as "outsiders" if they rely only on their "automatic modes". In other words, the automatic mode would not make the Flamengo fan inclined to cooperate with the Fluminense supporter, if their soccer rivalry is the sole consideration. Indeed they would hate each other. If, however, both realize that they both have children with visual impairments, or that both defend liberal ideology, a certain empathy arising from their perceived identity in that other group could minimize or neutralize that rivalry.

One way or another, those ideas clearly reveal that it is possible, even within a "descriptive" and "empirical" paradigm, to deal with ethical or moral issues and investigate their origin and foundations in order to find ways to use them in favor of a more fitting solution to moral issues that otherwise could be seen as insoluble or even impossible to be studied and discussed. Knowing how knowledge about such moral sentiments should be used, or which of those sentiments should be encouraged (altruism) and which should be minimized (hostility toward people seen as "different" or from "another group") certainly involves philosophical reflections, but we cannot simply state that moral sentiments are metaphysical and therefore impossible to be scientifically analyzed.

We can see how thin the line between fact-based judgments and value judgments is. Naturally, one may still work under this distinction. Some might argue, and not entirely without reason, that not all products of natural selection must be optimized and enhanced by men. After all, feelings such as aggressiveness also stem from that division, as do many other instincts and feelings that men often try to inhibit or minimize. If naturally selected moral sentiments give us the foundations of various "positive morals" that exist around the world, rational examination of those same sentiments, their goals and, considering such goals, their flaws, may enable us to develop a meta-morality that could help in resolving conflicts between different moral systems. As noted above, this could be related to the maximization of individual freedoms.

One might say, however, that the discussion here should not revolve around Morals, but Natural Law instead. The words "Moral" and "Natural Law", nevertheless, can be used interchangeably, especially when we talk about an ideal paradigm based on which positive law can be assessed. The natural source of such moral sentiments - and of their insufficiency, which is to be addressed by a rationally grounded meta-morality that resolves possible conflicts - applies equally to the idea of natural law, which experiences one more rebirth.

As for the above-mentioned mirror neurons which allow human beings to put themselves into someone else's shoes, not only have they enabled moral sentiments and empathy, they, and the more sophisticated neurological structure that works with them in human beings, have also enabled institutional realities, that is, realities that only exist because they are inter-subjectively accepted ${ }^{45}$. From those realities arises culture, and along with culture, arise notions such as money and law, which only exist because their existence is inter-subjectively accepted.

In order to be recognized by those who submit to it, the law, as a legal order, and its substance, must be close to what the people deem desirable. Obviously, a

45 SEARLE, John. Libertad y neurobiologia. Tradução de Miguel Candel. (Barcelona: Paidós, 2005), 103. 
complete coincidence is impossible, utopian and unattainable. Nonetheless, that does not mean that a possible approach should not be attempted. The greater the proximity, the greater the level of recognition of a legal order as such, and the greater its distinction from the mere use of organized power.

Within this context, freedom, equality and democracy appear as possible universal foundations upon which all legal systems should be organized, in order to meet, in its contents, the expectations of those who submit to them ${ }^{46}$. This allows "natural law", which is inherent to mankind because of natural selection, to be a part, to a certain extent, of positive law propositions and to be corrected and improved toward a more effective legal system.

We could say, to a certain extent, that those ideas also arise in the "naturalistic fallacy". After all, why would we want to build a more efficient and reputable legal system which is considered fairer by those who submit to it? As for the fact that the concept of justice is highly indeterminate, would this amount to disregard such pretensions? As a matter of fact, no. Doctors do not consider any less scientific, research that intends to discuss a swifter or painless surgical procedure, or that increases the patient's welfare, regardless of the subjective nature of those ideas The same can be said of research designed to discover how to manufacture more economical and safer cars, or to find cheaper and less polluting sources of energy. If the Law is an institutional reality, measures that increase the recognition of its rules as an expression of the law, and not as a mere exercise of power, intend to make it better. In other words, that is the same ideal that inspires those involved in the study of other parts of reality. We obviously cannot confuse what the law is with what the law should be. In fact, the point is to describe it as it is understood while allowing for its improvement, in an attempt to make it closer to what it should be. Regardless of whether one is considering "positive moralities", , i.e. moral rules that actually exists in every community, or "critical or ideal morality", understood as a meta-criterion for judging several moral systems found in different societies, the possibility of disagreements should not cause the discussion to be abandoned, with respect to the values that should guide the evaluation and the improvement of reality as it is. The first reason is because we also find divergence and disagreement in sciences that are regarded as being more descriptive and objective, such as physics and biology. Setting aside unreasonable disagreements, like the ones that deny natural selection and claim that fossils are the record of animals that were unable to board Noah's Ark, there are founded disagreements that are currently insoluble, namely among theoretical physicists, and that surround key issues in the understanding of Universe. That disagreement is no reason for considering those topics as inferior, subjective or impossible to be debated ${ }^{47}$. Moral issues are not merely personal tastes; so much so that people give reasons to defend points of view regarding moral issues (same sex marriage, abortion etc.), but refrain from doing the same in a "discussion" about the best ice cream flavor ${ }^{48}$. Moreover, the fact that there is disagreement on the optimal solution for certain problems does not mean that the same issue cannot be encountered in every kind of moral dilemma. Lack of consensus about what is perfect does not mean that it is not possible to solve situations for which there is consensus about its imperfection. In other words, eventually it is possible to reach consensus about the necessity of correcting something, although people cannot agree about what would

\footnotetext{
$\overline{46}$ MACHADO SEGUNDO, Hugo de Brito. Fundamentos do Direito. (São Paulo: Atlas, 2010), 87.

47 ZIMMERMAN, Aaron. Moral epistemology. (New York: Routledge, 2010), 100; TERSMAN, Folke. Moral desagreement. (New York: Cambridge University Press, 2006), xi.

48 BENN, Piers. Ethics. (London: UCL, 1998), 5.
} 
be ideal ${ }^{49}$. Those issues can therefore be discussed openly, supported by empirical and experimental data, but, in one way or another, scientifically.

\section{Final considerations}

Moral sentiments currently appear to be less "metaphysical" than they seemed to be to scientists a few centuries or even decades ago, especially to social scientists. Without ignoring the fact that this statement may be subject to refutation, as any other statement that claims to be scientific, one can determine the origins, the purpose and even the failures of moral sentiments.

Based on those notions, we may witness another revival of ideas related to "natural law". This might open up new opportunities for discussion on the topic and its interaction with the development and interpretation of positive law.

Among those opportunities is the research about mechanisms to resolve conflicts arising from the contrast between different cultural and moral standards, one of the dilemmas of contemporary times. The best way to address such questions seems to be the one that maximizes freedom - and not exactly happiness - to the greatest number of people, under an enhanced perspective of utilitarianism. This option that is admittedly prescriptive; however this aspect on its own should not make us abandon the proposition.

We are not defending the return to classical natural law or to an eternal and unchanging ideal of justice. Notwithstanding, such ideas allow us at the very least to consider moral judgments as something less abstract and subjective and enable rational discussions about them, their grounds and their possible relationships with positive law without the fear of being less "scientific".

This paper is not suggesting either that moral sentiments or any other instinct or automatic behavior shaped by natural selection should determine everything when it comes to human behavior. Strictly speaking, contemporary biology has shown that human beings are more "feral" than we used think, and that other animals have characteristics or traits that were previously imagined to be exclusively human. In fact, what happens is that the boundaries between humans and other animals are gradual and blurred, as is the case with virtually all separations we see in the phenomenal world. Of course there are human components that make us different. Those components allow for culture to emerge, and together with it differences in how those sentiments and instincts are implemented throughout time and space also occur. Just as there is a biological foundation for languages to emerge, with many different dialects, human beings have a natural inclination toward certain nutrients, which are, nevertheless, used to make different typical dishes in different parts of the world. The same occurs with moral sentiments.

\footnotetext{
49 SEN, Amartya. The idea of justice. (Cambridge, Massachusetts: Harvard University Press, 2009) 2009, p. 104; LUKES, Steven. Moral relativism. (New York: Picador, 2008) 154.
} 